\title{
Czy leki inkretynowe i inhibitory SGLT-2 mogą znaleźć zastosowanie w leczeniu cukrzycy typu 1?
}

\author{
Can incretin-based therapy and SGLT-2 inhibitors may be useful \\ in the treatment of diabetes type 1 ?
}

\section{STRESZCZENIE}

Wiadomo, że insulinoterapia stanowi podstawę leczenia cukrzycy typu 1. Wiąże się ona jednak z występowaniem częstych epizodów hipoglikemii i w wielu przypadkach z przyrostem masy ciała, rozwojem insulinooporności. Dlatego też w terapii cukrzycy typu 1 podejmuje się próby dodatkowego podania metforminy. Pojawiają się ostatnio doniesienia o korzystnym addytywnym wpływie na kontrolę glikemii u osób z cukrzycą typu 1 agonistów inkretyn (GLP-1), inhibitorów dipeptydyl peptydazy 4 (DPP-4) oraz inhibitorów kotransportera glukozo-sodowego 2 (SGLT-2). (Diabet. Klin. 2015; 4, 4: 147-151)

Słowa kluczowe: cukrzyca typu 1, leki inkretynowe, inhibitory SGLT-2

\section{ABSTRACT}

It is known, that insulin therapy is essential in the treatment of type 1 diabetes. Insulin therapy has been related with some side effects such as hypoglycemia and weight gain, strongly connected with insulin resistance. Therefore the metformin is used sometimes as additive therapy In patients with type 1

\footnotetext{
Adres do korespondencji:

lek. Paulina Różańska

Klinika Chorób Wewnętrznych i Diabetologii

Uniwersytetu Medycznego im. Karola Marcinkowskiego w Poznaniu

e-mail: prozanska@poczta.onet.pl

Diabetologia Kliniczna 2015, tom 4, 4, 147-151

DOI: 10.5603/DK.2015.0015

Nadesłano: 21.06.2015

Przyjęto do druku: 26.07.2015
}

diabetes. Recently, glukagon-like peptide 1 (GLP-1) analogs, dipeptydyl peptidase 4 (DPP-4) inhibitors and sodium glucose co-transporter 2 inhibitors (SGLT-2) has been raported to be beneficial for the glycemic control in type 1 diabetic. (Diabet. Klin. 2015; 4, 4: 147-151)

Key words: diabetes mellitus type 1, incretin-based therapy, SGLT-2 inhibitors

Cukrzyca obecnie jest zaliczana do heterogennej grupy chorób metabolicznych, których wspólną cechą jest hiperglikemia. Rozwija się ona w następstwie zaburzeń czynności wydzielniczej komórek beta wysp trzustki prowadzących do zmniejszenia sekrecji insuliny. Inną przyczyną schorzenia może być zmniejszenie lub brak wrażliwości komórek mięśniowych, tkanki tłuszczowej i wątroby na działanie tego hormonu. Cukrzyca należy do najczęstszych chorób przewlekłych współczesnej cywilizacji. W Polsce u ponad $2 \mathrm{mln}$ ludzi rozpoznano cukrzycę, w tym u około 250 tys. cukrzycę typu 1. Leczenie zaburzeń gospodarki węglowodanowej stanowi jeden z najważniejszych problemów współczesnej medycyny. Wyniki badania United Kingdom Prospective Diabetes Study (UKPDS) wykazały, że dobra kontrola metaboliczna cukrzycy typu $2\left(\mathrm{HbA}_{1 \mathrm{c}}<7 \%\right)$ od początku choroby jest w stanie zmniejszyć częstość występowania groźnych dla życia powikłań mikro- i makroangiopatycznych (miażdżycowych) [1]. Uzyskane w tym zakresie wyniki są jednak nadal niezadowalające, ponieważ choroba jest rozpoznawana zbyt późno, naturalna jest jej stopniowa progresja, a stosowane leki, chociaż skuteczne na początku choroby, w okresie późniejszym nie zabezpie- 
czają w pełni wyrównania metabolicznego. Ponadto, dla uzyskania pozytywnych wyników leczenia konieczna jest zmiana nawyków behawioralnych, co jest niezwykle trudne zwłaszcza u starszych osób [2]. W celu poprawy kontroli glikemii podejmowana jest wówczas terapia wielolekowa, a w kolejnym etapie insulinoterapia. Jednak bez zmiany sposobu żywienia i włączenia aktywności fizycznej, metody te nie zawsze są skuteczne. Dlatego też opracowuje się kolejne leki, stwarzające nadzieję na długotrwałą poprawę wyrównania metabolicznego cukrzycy. Do grupy względnie nowych leków stosowanych w terapii cukrzycy typu 2 zalicza się między innymi leki inkretynowe [3, 4]. Inkretyny odgrywają ważną rolę $w$ regulacji homeostazy glukozy u osób zdrowych. Fizjologicznie, podanie doustne glukozy powoduje wydzielenie nawet 3-krotnie większej ilości insuliny w porównaniu z efektem wywołanym przez tę samą ilość glukozy podanej dożylnie. Nasilenie działania hipoglikemizującego, zależnego od wpływu hormonów uwalnianych przez komórki przewodu pokarmowego, nazwano efektem inkretynowym. Zjawisko to koreluje pozytywnie z ilością spożytych węglowodanów. Zasadniczymi hormonami odpowiedzialnymi za efekt inkretynowy są: polipeptyd insulinotropowy zależny od glukozy (GIP, glucose-dependent insulinotropic polypeptide) oraz glukagonopodobny peptyd 1 (GLP-1, glucagon-like peptide 1). Obie inkretyny są wydzielane w odpowiedzi na bodziec pokarmowy i powodują zwiększoną sekrecję insuliny, zarówno u osób zdrowych, jak i chorych na cukrzycę. Ich efekt wiążę się przede wszystkim z nasileniem wydzielenia insuliny w odpowiedzi na hiperglikemię. W badaniach doświadczalnych wykazano, że GLP-1 korzystnie wpływa także na masę komórek beta wysp trzustki, zarówno poprzez nasilenie ich proliferacji, jak i ograniczenie apoptozy. Wydaje się mieć to szczególne znaczenie w aspekcie możliwości zastosowania leków inkretynowych, także w terapii cukrzycy typu 1 [5].

Badanie The Diabetes Control and Complications Trial (DCCT) zakończone w 1993 roku jednoznacznie udowodniło, że podstawowym warunkiem prawidłowego przebiegu choroby i zapobiegania rozwojowi groźnych dla życia powikłań, jest wczesne rozpoznanie cukrzycy i jej prawidłowe leczenie od początku choroby, z utrzymywaniem stężenia glukozy we krwi w granicach zbliżonych do wartości fizjologicznych [6]. Ponadto, badanie to wskazało na model intensywnej insulinoterapii jako jedynej skutecznej metody walki z hiperglikemią w przebiegu cukrzycy typu 1. W czasie Kongresu Amerykańskiego Towarzystwa Diabetologicznego w 1993 roku, na podstawie przedstawionych po raz pierwszy wyników badania DCCT, sformułowano obowiązujące do dzisiaj zalecenie dla lekarzy prakty- ków: „Intensywna terapia, umożliwiająca osiągnięcie stężeń glukozy we krwi w granicach wartości notowanych u osób bez cukrzycy, powinna być stosowana u większości pacjentów z IDDM".

Korzystne wyniki modelu intensywnej insulinoterapii w cukrzycy typu 1 potwierdziło badanie obserwacyjne Epidemiology of Diabetes Interventions and Complications (EDIC), stanowiące kontynuację badania DCCT. Ujawniło ono znacznie mniejszą progresję powikłań cukrzycy u osób leczonych intensywnie w porównaniu z grupą osób stosujących konwencjonalny model insulinoterapii. Te korzystne wyniki leczenia intensywnego utrzymywały się pomimo wyraźnego pogorszenia kontroli metabolicznej w ciągu 8 lat od zakończenia badania DCCT [7].

Jednak ta najbardziej fizjologiczna strategia leczenia ma także, zwłaszcza u osób niedostatecznie wyedukowanych lub niestosujących się do zaleceń, swoje ujemne strony. Przyczynić się może bowiem do wzrostu ich masy ciała i rozwoju insulinooporności [6]. Zwiększone zapotrzebowanie na insulinę pogarsza wyrównanie metaboliczne cukrzycy typu 1, sprzyjając rozwojowi przewlekłych powikłań. Dlatego, coraz częściej pojawiają się doniesienia o możliwości wykorzystania metforminy jako terapii uzupełniającej w leczeniu cukrzycy typu 1 [8-11]. Pozwala ona bowiem nie tylko na poprawę kontroli glikemii, lecz również na zmniejszenie dawki dobowej insuliny. Znane jednak działania niepożądane tego leku w postaci dolegliwości żołądkowo-jelitowych (biegunki i zaparcia, metaliczny smak w ustach i uczucie suchości w ustach, nudności) mogą przyczynić się do odstawienia metforminy z powodu jej nietolerancji. Podejmuje się więc próby u osób z cukrzycą typu 1 zastosowania nowej generacji leków przeciwcukrzycowych w skojarzeniu z insulinoterapią. Jednym z nich są leki z grupy inkretyn [11].

\section{Leki z grupy inkretyn w terapii cukrzycy typu 1}

Leki inkretynowe działają na dwa sposoby. Pierwszy z nich w postaci agonisty receptora GLP-1 - eksenatydu, liraglutydu, liksisenatydu, nasila sekrecję insuliny przy narastającej glikemii. Druga strategia polega na blokowaniu działania enzymu DPP-4 (inhibitory DPP-4). Aktualnie w Polsce zarejestrowane są: sitagliptyna, wildagliptyna, saksagliptyna oraz linagliptyna [4]. Leki inkretynowe stanowią nowy rozdział w terapii cukrzycy, ponieważ wydają się być pozbawione niekorzystnych działań. Podczas ich stosowania w monoterapii nie występuje hipoglikemia, a ponadto powodują wolniejsze opróżnienie żołądka i zahamowanie łaknienia. Mają więc wpływ na redukcję masy ciała, a tym samym na zmniejszenie stopnia insulinooporności. Bezpieczeń- 
stwo stosowania leków tej grupy w cukrzycy typu 2 wykazano w wielu badaniach klinicznych. Jednak opublikowano dotychczas tylko nieliczne doniesienia dotyczące badań nad wpływem leków inkretynowych w terapii cukrzycy typu 1 [12].

Badania doświadczalne przeprowadzone u myszy sugerują, że komórki beta wysp trzustki mają duży potencjał do zwiększania swojej masy pod wpływem inkretyn [13]. Na tej drodze mogą wpływać na długość remisji w świeżo rozpoznanej cukrzycy typu 1. Wykazano również, ze eksenatyd poprawia funkcje przeszczepionych komórek beta u pacjentów z cukrzycą typu 1 [14]. Zao i wsp. zaobserwowali z kolei, że sitagliptyna utrzymuje funkcję komórek beta u osób ze świeżo rozpoznaną cukrzycą LADA [15]. W badaniach eksperymentalnych ujawniono ponadto, że podanie inkretyn szczurom z cukrzycą typu 1 powoduje uszczelnienie bariery naczyniowej, zmniejszenie towarzyszącego hiperglikemii odczynu zapalnego i ograniczenie śmierci neuronów [16]. Sugerować to może ich udział w prewencji lub zmniejszaniu progresji cukrzycowych powikłań mikronaczyniowych. Ten punkt widzenia potwierdzają badania Kodera i wsp., którzy na podobnym modelu zwierzęcym wykazali korzystny wpływ inkretyn na hamowanie rozwoju wczesnych stadiów uszkodzenia nerek [17]. Stwierdzono również, że efekt ich działania zanika szybko po zaprzestaniu leczenia [14]. Jest więc możliwe, że ta klasa leków może przedłużać funkcjonowanie komórek beta wysp trzustki u ludzi z cukrzycą typu 1 i zachowaną jeszcze sekrecją insuliny.

Sitagliptyna jest wybiórczym inhibitorem DPP-4 zarejestrowanym w terapii cukrzycy typu 2 celem poprawy kontroli glikemii, zarówno w monoterapii (u chorych nietolerujących metforminy), jak i w skojarzeniu z metforminą, pochodną sulfonylomocznika czy tiazolidynedionu. Nie posiada ona dotychczas zarejestrowanych wskazań w terapii cukrzycy typu 1. Sugeruje się jednak ostatnio, żeby rozszerzyć zastosowanie inhibitorów DDP-4 również do terapii tej grupy osób. Giampietro i wsp. w badaniu porównującym efekt długoterminowego podawania łącznie sitagliptyny i metforminy lub samej sitagliptyny (przy nietolerancji metforminy) wykazali, że terapia z użyciem DPP-4 może być skuteczna także u osób z typem 1 cukrzycy [19]. Badaniem objęto grupę 25 pacjentów z typem 1 cukrzycy i 31 z typem 2 choroby, leczonych dotychczas wyłącznie insuliną. Po uzupełnieniu dotychczasowego modelu terapii przez dodanie sitagliptyny i metforminy lub samej sitagliptyny pacjentów obserwowano odpowiednio 46 i 56 tygodni. Po 21 tygodniach w grupie pacjentów z typem 1 cukrzycy odnotowano znaczące obniżenie wskaźnika masy ciała (BMI, body mass index), wartości glikemii na czczo oraz obniżenie wartości $\mathrm{HbA}_{1 c^{\prime}}$ przy równocześnie zmniejszonym dobowym zapotrzebowaniu na insulinę. Po 46 tygodniach obserwacji utrzymał się nadal w tej grupie osób znaczący spadek masy ciała i dobowej dawki insuliny, a także stężenia cholesterolu frakcji LDL, przy porównywalnych do wyjściowych wartościach $\mathrm{HbA}_{1 \mathrm{c}}$. To pierwsze badanie oceniające długoterminowe zastosowanie sitagliptyny w cukrzycy typu 1 wykazało, że wyniki różnią się w zależności od czasu trwania terapii. Stwierdzono ponadto, że dodanie do insulinoterapii leków poprawiających wrażliwość tkanek obwodowych na jej działanie w sposób wyraźny poprawia kontrolę metaboliczną, profil lipidowy oraz wpływa na redukcję dobowej dawki insuliny w obu typach cukrzycy. U pacjentów z typem 1 choroby korzystny wpływ na kontrolę glikemii był jednak tylko przejściowy, mimo redukcji masy ciała utrzymującej się w tej grupie osób również po zakończeniu terapii.

W czasopiśmie „Enodcrinology, Diabetes\& Metabolism Case Report" opisano przypadek 19-letniego chłopca z cukrzycą typu 1, z dodatnimi przeciwciałami anty-GAD oraz z kwasicą ketonową w momencie rozpoznania choroby. Na początku terapii BMI chłopca wynosiło $20,8 \mathrm{~kg} / \mathrm{m}^{2}$, stężenie glukozy we krwi na czczo - $432 \mathrm{mg} / \mathrm{dl}$, wartość $\mathrm{HbA}_{1 \mathrm{c}}-12 \%$, a stężenie C-peptydu - 1,2 ng/ml. Zastosowano wówczas typowe leczenie kwasicy, a następnie rozpoczęto insulinoterapię $z$ użyciem glarginy i glulizyny w dobowej dawce 0,5 j./kg mc./dobę. Już po 72 godzinach osiągnięto zadowalające wyrównanie glikemii. Po ustąpieniu zaburzeń gospodarki kwasowo-zasadowej, do leczenia insuliną dołączono sitagliptynę w dawce $100 \mathrm{mg}$ na dobę. Zaobserwowano stopniowe zmniejszanie się zapotrzebowania na insulinę, a po około 8 tygodniach całkowicie zrezygnowano z jej stosowania z powodu wystąpienia klinicznej remisji choroby. W następnym okresie pacjent otrzymywał sitagliptynę w monoterapii, uzyskując stężenie glukozy we krwi w granicach 70-130 mg/dl i redukcję $\mathrm{HbA}_{1 c}$ do wartości 7,8\%. Insulinoterapia nie była konieczna przez okres około roku. W tym czasie masa ciała pacjenta obniżyła się o $7 \mathrm{~kg}$. Odnotowano również zmniejszenie miana przeciwciał anty-GAD, a stężenie C-peptydu w surowicy utrzymywało się na wyjściowym poziomie. Po roku terapii sitagliptyną wykazano dalszą redukcję $\mathrm{HbA}_{1 c}$ o 5,8\%, oraz wartości glikemii na czczo [19].

W przytoczonym badaniu podjęto próbę zastosowania sitagliptyny w terapii cukrzycy typu 1 z uwagi na rosnącą liczbę dowodów wskazujących na korzystny wpływ inhibitorów DPP-4 na redukcję zapotrzebowania na insulinę i poprawę kontroli metabolicznej, bez znaczącego ryzyka hipoglikemii w cukrzycy typu 1. Co prawda, jest to dotychczas jedyny przykład uzyskania remisji u osoby z cukrzycą typu 1 leczonego sitaglipty- 
ną, dlatego też zagadnienie to wymaga dalszych badań. Nie można również wykluczyć, że w tym przypadku długotrwała remisja wystąpiłaby także bez zastosowania leku z grupy inkretyn, czy jakichkolwiek innych [20]. Jednakże również badanie Ellis i wsp. wykazało korzystny wpływ sitagliptyny na redukcję stężenia glukozy we krwi, zarówno wartości poposiłkowej, jak i ocenianej w profilu dobowym u pacjentów z cukrzycą typu 1 [21].

Godne odnotowania są również wyniki szwedzkich badań oceniających wpływ wildagliptyny na czynność komórek alfa wysp trzustki u osób chorych na cukrzycę typu 1 [22]. Wykazały one, że wildagliptyna działa supresyjnie na wydzielanie glukagonu w czasie hiperglikemii poposiłkowej. Przyjmowanie wildagliptyny nie zaburzyło natomiast korzystnej odpowiedzi glukagonu w sytuacji hipoglikemii (ocenianej na podstawie wzrostu stężenia adrenaliny, noradrenaliny, kortyzolu) w tej grupie pacjentów. W warunkach fizjologicznych, na wydzielanie glukagonu przez komórki alfa supresyjnie wpływa poposiłkowy wzrost sekrecji insuliny przez komórki beta. Natomiast w cukrzycy typu 1, hiperglukagonemia pojawia się jako wyraz nieefektywnego wydzielania insuliny w odpowiedzi na posiłek, a także glukotoksycznego wpływu hiperglikemii na komórki alfa. U pacjentów z cukrzycą typu 2 wykazano z kolei, że wzrost stężenia glukagonu po posiłku prowadzi do nasilenia wątrobowej produkcji glukozy, a przez to do hiperglikemii. Badania Ramana i wsp. pokazują, że natywny GLP-1 zmniejsza hiperglikemię poposiłkową również w cukrzycy typu 1, prawdopodobnie przez wpływ na supresję glukagonu. Podobny efekt zaobserwowano po iniekcjach eksanatydu u młodych pacjentów z cukrzycą typu 2 [23]. W badaniach z zastosowaniem liraglutydu udało się także wykazać jego korzystny wpływ na kontrolę glikemii poposiłkowej. Efekt codziennego stosowania liraglutydu oceniono u 14 pacjentów z dobrze wyrównaną cukrzycą typu 1, leczonych metodą intensywnej insulinoterapii. Część pacjentów zakończyła obserwacje po tygodniu, a 8 kontynuowało terapię przez 24 tygodnie. U wszystkich pacjentów odnotowano redukcję wartości glikemii oraz spadek zapotrzebowania na insulinę. U osób kontynuujących terapię przez 24 tygodnie wykazano nie tylko istotne statystycznie obniżenie wartości glikemii, redukcję dawki insuliny oraz obniżenie wartości $\mathrm{HbA}_{1 c^{\prime}}$ lecz także zmniejszenie masy ciała [24]. Zbliżone wyniki uzyskali także inni autorzy $[25,26]$.

\section{Leki z grupy inhibitora kotransportera sodowo-glukozowego 2 ( SGLT-2)}

Atrakcyjne uzupełnienie grupy leków hipoglikemizujących w cukrzycy typu 1 mogą stanowić, z uwagi na odmienny, „pozainsulinowy” mechanizm działania, inhibitory SGLT-2. Leki z grupy inhibitora kotransportera sodowo-glukozowego 2, hamując transport zwrotny glukozy w cewce bliższej kanalików nerkowych, zmniejszając próg nerkowy dla glukozy, nasilają glukozurię. Ilość glukozy usuwanej przez nerki dzięki mechanizmowi ich działania zależy od stężenia glukozy we krwi i stopnia filtracji kłębuszkowej (GFR, glomerular filtration rate). Tym samym zmniejszają jej toksyczny wpływ na czynność komórek wielu narządów, a zwłaszcza na funkcję komórek beta wysp trzustki. Skuteczność tej grupy leków w obniżaniu wartości glikemii dobrze oceniono $w$ wielu badaniach klinicznych prowadzonych u osób z cukrzycą typu 2. Stwierdzono, że inhibitory SGLT-2 stosowane zarówno w monoterapii, jak i w terapii skojarzonej, cechują się podobną skutecznością jak inhibitory DPP-4 czy metformina. Mają jednak nieco słabsze działanie przeciwhiperglikemiczne niż pochodne sulfonylomocznika. Ważną zaletą inhibitorów SGLT-2 jest ich wpływ na wyraźne zmniejszanie masy ciała i obniżanie ciśnienia tętniczego w okresie ich stosowania. Leki te, ograniczając zapotrzebowanie na insulinę, zapobiegają leczeniu zbyt dużymi dawkami jej preparatów, a tym samym ograniczają przyrost masy ciała. Obserwacje te stały się przyczyną rekomendacji wykorzystywania SGLT-2 w skojarzeniu z insuliną.

Terapia insuliną w cukrzycy typu 1 wiąże się często z dużymi wahaniami glikemii, zagrożeniem hipoglikemią, a także ze wzrostem masy ciała. Ostatnio ukazały się wyniki pracy Henry i wsp., którzy przeprowadzili randomizowane badanie $z$ użyciem podwójnie ślepej próby, w celu oceny możliwości zastosowania dapaglizflozyny w terapii pacjentów z cukrzycą typu 1 [27]. Badanie trwało 2 tygodnie, obejmowało 70 osób dorosłych z typem 1 cukrzycy, z wartością $\mathrm{HbA}_{1 c}$ w granicach 7-10\%, którzy leczeni byli insuliną w stabilnych dawkach. Do podstawowej terapii dołączano dapagliflozynę w jednej z czterech dawek (1, 2,5, 5, 10 mg) lub placebo. Oceniano między innymi krótkoterminowe bezpieczeństwo tego rodzaju terapii. Epizody hipoglikemii odnotowano włącznie w grupie placebo. Zgodnie z oczekiwaniami zaobserwowano zwiększone, zależne od dawki dapagliflozyny, dobowe wydalanie glukozy z moczem. Dane uzyskane z ciągłego monitorowania glikemii wskazywały na znaczącą redukcję wartości stężenia glukozy we krwi. Zanotowano także istotne zmniejszenie dobowej dawki insuliny w siódmym dniu obserwacji, jednak tylko w grupach stosujących 5 mg (o 19\%) lub $10 \mathrm{mg}$ (o 16\%) dapagliflozyny. Lek był dobrze tolerowany u wszystkich ocenianych pacjentów. Po zakończeniu analizy podkreślono konieczność kontynuowania badań nad zastosowaniem inhibitorów kotransportera sodowo-gukozowego w cukrzycy typu 1. 
Godne uwagi jest również badanie przeprowadzone przez Perkinsa i wsp. dotyczące innego inhibitora SGLT-2 - empagliflozyny (lek niezarejestrowany dotychczas w Polsce) [28]. W badaniu wzięło udział 40 pacjentów z cukrzycą typu 1, z prawidłowym ciśnieniem tętniczym, z normoalbuminurią i wartością $\mathrm{HbA}_{1 \mathrm{c}}$ w granicach $6,5-11,0 \%$. Przez okres 8 tygodni przyjmowali oni $25 \mathrm{mg}$ empagliflozyny, jako uzupełnienie podstawowej terapii insuliną. Badane składało się z trzech części: w 2 pierwszych tygodniach do insulinoterapii dodawano placebo, w kolejnych 8 tygodniach zmieniano placebo na oceniany lek, a dalszy dwutygodniowy okres wiązał się z oceną efektu terapii po odstawieniu leku. Uzyskane wyniki wykazały, że ośmiotygodniowa terapia empagliflozyną przyczyniła się do poprawy kontroli glikemii, redukcji epizodów hipoglikemii, zmniejszenia dobowej dawki insuliny oraz redukcji masy ciała.

Podsumowując, można stwierdzić, że leki inkretynowe i inhibitory SGLT-2 wydają się być skuteczne i bezpieczne nie tylko w terapii cukrzycy typu 2. Można sugerować, że w najbliższej przyszłości będą one stanowiły dodatkową opcję terapeutyczną uzupełniającą insulinoterapię w leczeniu cukrzycy typu 1 [29]. Ich korzystny wpływ na funkcję komórek sekrecyjnych wysp trzustki, na poprawę parametrów wyrównania metabolicznego oraz na redukcję masy ciała stwarza takie nadzieje, chociaż możliwość ich wykorzystania w tym typie choroby wymaga jeszcze dalszych badań klinicznych.

\section{Oświadczenie o konflikcie interesów Autorzy nie zgłaszają konfliktu interesów.}

\section{PIŚMIENNICTWO}

1. UKPDS Group: Intensive blood-glucose control with sulphonylureas or insulin compared with conventional treatment and risk of complications in patients with type 2 diabetes (UKPDS 33). Lancet 1998; 352: 837-858.

2. Turner R.C., Cull C.A., Frighi N. i wsp. Glycemic control with diet, sulfonylurea, metformin, or insulin in patients with type 2 diabetes mellitus. Progressive requirement for multiple therapies (UKPDS 49). JAMA 1999; 281: 2005-2012.

3. Pratley R.E. Overview of glucagonlike peptide1 analogs and dipeptidyl peptidase4 inhibitors for type 2 diabetes. Medscape J. Med. 2008; 10: 1719-1724.

4. Znaniecka M., Rutkowska J., Bandurska-Stankiewicz E. Nowy kierunek w leczeniu cukrzycy - inkretynomimetyki oraz inhibitory DPP-4. Przegląd Kardiodiabetologiczny 2010; 5: 4-7.

5. Scheen A.J. A review of gliptins for 2014. Expert Opin Pharmacother. 2015; 16: 43-62.

6. Diabetes Control and Control and Complications Research Group: The effect of intensive treatment of diabetes on the development and progression of long-term complications in insulin-dependent diabetes mellitus. New Engl. J. Med. 1993; 329: 977-986.

7. Epidemiology of Diabetes Interventions and Complications (EDIC) Research Group: Epidemiology of Diabetes Interventions and Complications (EDIC). Design, implementation and preliminary results of long-term follow-up of Diabetes Control and Complications Trial cohort. Diabetes Care 1999; 22: 99-111.
8. Vella S., Buetow L., Royle P., Livingstone S., Colhoun H.M., Petrie J.R. The use of metformin in type 1 diabetes: a systemic review of efficacy. Diabetologia 2010; 53: 809-820.

9. Gunton J.E., Twigg S.M. Metformin use as an adjunct to insulin treatment in selected patients with type 1 diabetes mellitus. Med. J. Aust. 2003; 178: 591-592.

10. Liu C., Wu D., Zheng X., Li P., Li L. Efficacy and safety of metformin for patients with type 1 diabetes mellitus: a meta-analysis. Diabetes Technol. Ther. 2015; 17: 142-148.

11. Zibar K., Ćuća J.K., Blaslov K., Bulum T., Smirčić-Duvnjak L. Difference in glucagon-like peptide-1 concentrations between C-peptide negative type 1 diabetes mellitus patients and healthy controls. Ann. Clin. Biochem. 2015; 52: 220-225.

12. Unger J. Rationale use of GLP-1 receptor agonists in patients with type 1 diabetes. Curr. Diab. Rep. 2013; 13: 663-668.

13. Kim S.J., Nian C., Doudet D.J., McIntosh C.H. Dipeptidylpeptidase IV inhibition with MK0431 improve sisley graft survival in diabetic NOD mice partially via T-cellmodulation. Diabetes 2009; 58: 641-651.

14. Ghofaili K.A., Fung M., Ao Z. i wsp. Effect of exenatide on beta cell function after islet transplantation in type 1 diabetes. Transplantation 2007; 83: 24-26.

15. Zhao Y., Yang L., Xiang Y. i wsp. Dipeptidyl peptidase 4 inhibitor sitagliptin maintains $\beta$-cell function in patients with recent-onset latent autoimmune diabetes in adults: one year prospective study. J. Clin. Endocrinol. Metab. 2014; 99: E876-880.

16. Gonçalves A., Marques C., Leal E. i wsp. Dipeptidyl peptidase-IV inhibition prevents blood-retinal barrier breakdown, inflammation and neuronal cell death in the retina of type 1 diabetic rats. Biochim. Biophys. Acta. 2014; 1842: 1454-1463.

17. Kodera R., Shikata K., Takatsuka T. i wsp. Dipeptidyl peptidase-4 inhibitor ameliorates early renal injury through its anti-inflammatory action in a rat model of type 1 diabetes. Biochem. Biophys. Res. Commun. 2014; 443: 828-833.

18. Giampietro O., Giampietro C., Bartola L.D., Masoni M.C., Matteucci E. Sitagliptin as add-on therapy in insulin deficiency: biomarkers of therapeutic efficacy respond differently in type 1 and type 2 diabetes. Drug Des. Devel. Ther. 2013; 7: 99-104.

19. Lima-Martínez M.M., Guerra-Alcalá E., Contreras M., Nastasi J., Noble J.A., Polychronakos C. One year remission of type 1 diabetes mellitus in a patient treated with sitagliptin. Endocrinol. Diabetes Metab. Case Rep. 2014; 2014: 140072. DOI: 10.1530/EDM-14-0072.

20. Pilacinski S., Adler A.I., Zozulinska-Ziolkiewicz D.A., Gawrecki A., Wierusz-Wysocka B. Smoking and other factors associated with short-term partial remission of Type 1 diabetes in adults. Diabet. Med. 2012; 29: 464-469.

21. Ellis S.L., Moser E.G., Snell-Bergeon J.K., Rodionova A.S., Hazenfield R.M., Garg S.K. Effect of sitagliptin on glucose control in adult patients with Type 1 diabetes: a pilot, double-blind, randomized, crossover trial. Diabet. Med. 2011; 28: 1176-1181.

22. Farngren J., Persson M., Schweizer A., Foley J.E., Ahrén B. Vildagliptin reduces glucagon during hyperglycemia and sustains glucagon counterregulation during hypoglycemia in type 1 diabetes. J. Clin. Endocrinol. Metab. 2012; 97: 3799-3806.

23. Raman V.S., Mason K.J., Rodriguez L.M. i wsp. The role of adjunctive exenatide therapy in pediatric type 1 diabetes. Diabetes Care 2010; 33: 1294-1296.

24. Varanasi A., Bellini N., Rawal D. i wsp. Liraglutide as additional treatment for type 1 diabetes. Eur. J. Endocrinol. 2011; 165: 77-84.

25. Kielgast U., Krarup T., Holst J.J., Madsbad S. Four weeks of treatment with liraglutide reduces insulin dose without loss of glycemic control in type 1 diabetic patients with and without residual beta-cell function. Diabetes Care 2011; 34: 1463-1468.

26. Lind M., Jendle J., Torffvit O., Lager I. Glucagon-like peptide 1 (GLP-1) analogue combined with insulin reduces $\mathrm{HbA} 1 \mathrm{c}$ and weight with low risk of hypoglycemia and high treatment satisfaction. Prim. Care Diabetes 2012; 6: 41-46.

27. Henry R.R., Rosenstock J., Edelman S. i wsp. Exploring the potential of the SGLT2 inhibitor dapagliflozin in type 1 diabetes: a randomized, double-blind, placebo-controlled pilot study. Diabetes Care 2015; 38: 412-419.

28. Perkins B.A., Cherney D.Z., Partridge H. i wsp. Sodium-glucose cotransporter 2 inhibition and glycemic control in type 1 diabetes: results of an 8-week open-label proof-of-concept trial. Diabetes Care 2014; 37: 1480-1483.

29. Cherney D.Z., Perkins B.A. Sodium-glucose cotransporter 2 inhibition in type 1 diabetes: simultaneous glucose lowering and renal protection? Can. J. Diabetes 2014; 38: 356-363. 